\title{
Laporan kasus berbasis bukti Peran Reticulocyte Hemoglobin Content (RET-He) dalam Mendeteksi Defisiensi Besi pada Anak
}

\author{
Ika Maya Sandy, Murti Andriastuti \\ Departemen Ilmu Kesehatan Anak Fakultas Kedokteran Universitas Indonesia/ Rumah Sakit Dr. Cipto Mangunkusumo, Jakarta
}

\begin{abstract}
Latar belakang. Defisiensi besi (DB) didefinisikan sebagai penurunan total kandungan besi dalam tubuh yang ditandai dengan turunnya kadar feritin atau saturasi transferin. Gangguan perkembangan neurokognitif yang timbul akibat DB bersifat permanen. Identifikasi adanya DB penting untuk memulai terapi besi untuk mencegah komplikasi jangka panjang.

Tujuan. Mengetahui peran RET-He dalam mendeteksi DB pada anak dibandingkan dengan pemeriksaan biomarker penanda status besi lain (feritin, saturasi transferin, kadar besi serum, dan total iron binding capacity (TIBC)).

Metode. Penelusuran pustaka database elektronik, yaitu Pubmed, Cochrane, ProQuest dan Google scholar dengan kata kunci "iron deficiency", "AND" "reticulocyte hemoglobin content", "AND" "children".

Hasil. Penelusuran literatur diperoleh 4 artikel yang terpilih kemudian dilakukan telaah kritis. Studi oleh Mateos dkk, dengan level of evidence 1c, diperoleh nilai cut-off: $\leq 25$ pg, memiliki sensitivitas tertinggi dibanding studi lainnya, yaitu $94 \%$ dan spesifisitas $80 \%$, NDP 54\%, NDN 97\%. Studi lain menentukan nilai cut-off yang berbeda-beda sehingga memengaruhi nilai sensitivitas, spesifisitas, nilai duga positif dan negatif.

Kesimpulan. Berdasarkan penelitian ilmiah yang telah dipaparkan dapat disimpulkan bahwa RET-He dapat digunakan sebagai parameter untuk mendeteksi DB pada anak. Sari Pediatri 2019;20(5):316-23

Kata kunci: reticulocyte hemoglobin content (RET-He), defisiensi besi, anak

\section{Evidence base case report The Role of Reticulocyte Hemoglobin Content (RET-He) to Detect Iron Deficiency in Children}

Ika Maya Sandy, Murti Andriastuti

Background. Iron deficiency (ID) is defined as a condition where total body iron stores is depleted below the normal level characterized by low ferritin levels or transferrin saturation. Neurocognitive development disorders resulting from ID are permanent. Early identification of ID is important to start iron treatment to prevent long-term complications.

Objective. To compare reticulocyte hemoglobin content (RET-He) with other biomarkers of iron status (ferritin, transferrin saturation, serum iron levels, and total iron binding capacity (TIBC)) to detect ID among children. Method. Electronic literature searches using Pubmed, Cochrane, ProQuest and Google scholar with keywords "iron deficiency", "AND" "reticulocyte hemoglobin content", "AND" "children".

Results. Electronic literature searches, obtained four articles were eligible for critical appraisal. Study by Mateos et al. (level of evidence 1c) at the cut-off RET-He $\leq 25$ pg resulted in a highest sensitivity $94 \%$, specificity $80 \%$, PPV $54 \%$ and NPV $97 \%$, compared to other studies. Another study determined different cut-off values that influenced sensitivity, specificity, PPV and NPV.

Conclusion. RET-He can be utilized as a parameter to detect ID in children. Sari Pediatri 2019;20(5):316-23

Keywords: reticulocyte hemoglobin content (RET-He), iron deficiency, children

Alamat korespondensi: Murti Andriastuti. Departemen Ilmu Kesehatan Anak Fakultas Kedokteran Universitas Indonesia/ Rumah Sakit Dr. Cipto Mangunkusumo, Jakarta. Email: murtiandri@yahoo.com 


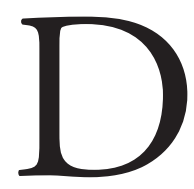
efisiensi besi (DB) dan anemia defisiensi besi (ADB) merupakan kondisi yang sering terjadi pada anak, khususnya di negara berkembang. ${ }^{1,2}$ Besi merupakan salah satu elemen mikronutrien yang penting. ${ }^{3}$ Defisiensi besi didefinisikan sebagai penurunan total kandungan besi dalam tubuh yang ditandai dengan turunnya kadar feritin atau saturasi transferin. Sedangkan ADB terjadi saat kondisi DB terjadi cukup berat sehingga mengurangi proses eritropoisis. ${ }^{4}$ Kekurangan besi dengan atau tanpa anemia, terutama yang berlangsung lama dan terjadi pada usia 0-2 tahun dapat mengganggu tumbuh kembang anak, antara lain menimbulkan defek pada mekanisme pertahanan tubuh dan gangguan pada perkembangan otak. ${ }^{3,4}$ Meskipun anemia dapat diobati, akan tetapi gangguan perkembangan neurokognitif yang timbul akibat DB bersifat permanen. ${ }^{4,5}$ Identifikasi adanya DB penting untuk memulai sedini mungkin terapi besi untuk mencegah komplikasi jangka panjang ADB. ${ }^{2-6}$ Secara umum diperkirakan 50\% anemia disebabkan oleh DB, namun proporsinya bervariasi pada berbagai populasi dan area serta dipengaruhi oleh kondisi lokal. ${ }^{2}$

Studi tahun 2016 terhadap anak Sekolah Dasar di Jakarta, prevalens anak yang memiliki status besi deplesi sebesar 4,3\%, DB sebesar 14,8\% dan ADB sebesar $1,7 \% .^{7,8}$ Studi pada populasi remaja dan dewasa muda dengan rentang usia subyek 10-21 tahun, prevalens kejadian $\mathrm{DB}$ sebesar $20 \%$ dan $\mathrm{ADB}$ hanya 5\%. ${ }^{9}$ Hal ini menunjukkan bahwa prevalens DB tanpa anemia lebih besar dibandingkan $\mathrm{ADB}$, oleh karena itu kita perlu mengetahui kejadian DB sebelum terjadinya anemia untuk mencegah efek jangka panjang akibat DB.

Pemeriksaan saturasi transferin merupakan pemeriksaan baku emas yang digunakan untuk mendiagnosis $\mathrm{DB}$, dengan menggunakan nilai batas $<10 \%$ pada anak usia berapapun memiliki sensitivitas dan spesifisitas $100 \%$. Saturasi transferin diperoleh dari perhitungan persentasekadar besi serum dibagi total iron binding capacity (TIBC). ${ }^{10}$ Parameter lain yang digunakan untuk skrining status besi adalah hemoglobin $(\mathrm{Hb})$, indeks eritrosit dan feritin. Namun, pemeriksaan tersebut tidak praktis untuk skrining karena dipengaruhi oleh variabilitas biologis, seperti variasi diurnal, makanan, dan inflamasi. Selain itu, memerlukan beberapa kali proses pengambilan darah dan mahal. ${ }^{11}$ Alternatif pemeriksaan laboratorium yang diharapkan dapat menanggulangi masalah tersebut dan telah direkomendasikan oleh American Academy of Pediatrics (AAP) adalah reticulocyte $\mathrm{Hb}$ content (RET-He). ${ }^{12}$ Kandungan retikulosit hemoglobin digunakan sebagai parameter baru untuk mendeteksi DB. Parameter ini mengukur kadar hemoglobin di retikulosit yang baru dilepaskan dari sumsum tulang dan diharapkan menggambarkan kondisi sebenarnya sumsum tulang sehingga bisa digunakan untuk mendeteksi DB sedini mungkin. Diharapkan RET-He dapat digunakan sebagai marker deteksi kekurangan besi yang murah, mudah dan aplikatif., ${ }^{6,13}$

Studi kasus berbasis bukti ini bertujuan untuk mengetahui peran RET-He dalam mendeteksi DB pada anak dibandingkan dengan pemeriksaan biomarker penanda status besi lain (feritin, saturasi transferin, kadar besi serum, dan total iron binding capacity (TIBC)).

\section{Kasus}

Seorang anak perempuan usia 8 tahun 7 bulan merupakan anak Sekolah Dasar Negeri (SDN) Pegangsaan 01 Pagi. Dilakukan pemeriksaan untuk skrining adanya DB. Pasien merupakan anak pertama, lahir cukup bulan, berat lahir 3100 gram, panjang lahir $50 \mathrm{~cm}$, secara spontan dengan bantuan bidan, langsung menangis tanpa resusitasi aktif. Tumbuh kembang kesan sesuai usia, saat ini pasien duduk di kelas 3 SD dengan prestasi rata-rata. Ayah pasien merupakan tukang ojek online dengan penghasilan rata-rata $\mathrm{Rp}$. 2.000.000,-/bulan dan ibu merupakan ibu rumah tangga. Pendidikan terakhir ayah Sekolah Menengah Pertama (SMP) dan ibu Sekolah Menengah Atas (SMA). Pasien tinggal di lingkungan padat penduduk dalam sebuah kamar sewa berukuran 4x6 $\mathrm{m}$ bersama ayah dan ibu. Asupan makanan keluarga tiga kali sehari dengan komposisi nasi, telur/ayam 2-3 kali seminggu, jarang makan sayuran, dan asupan daging hanya satu kali per tahun. Berat badan $41 \mathrm{~kg}$, tinggi badan $141 \mathrm{~cm}$, indeks masa tubuh (IMT) 117\% (p90-95 Kurva Centers for Disease Control and Prevention (CDC) 2000). Hasil pemeriksaan darah perifer lengkap: $\mathrm{Hb} 12,6 \mathrm{~g} / \mathrm{dL}, \mathrm{Ht}$ $38,6 \%$, eritrosit 5,31 10^ $6 / \mu \mathrm{L}, \mathrm{MCV} 72,70 \mathrm{fL}, \mathrm{MCH}$ 23,7 pg, MCHC 32,6 g/dL, trombosit 542.000/ $\mu \mathrm{L}$, leukosit 7.190/ $\mu \mathrm{L}$, RET-He 25,7 pg (rendah); besi 23 $\mu \mathrm{g} / \mathrm{dL}$ (rendah); TIBC $454 \mu \mathrm{g} / \mathrm{dL}$ (tinggi); feritin 9,49 $\mathrm{ng} / \mathrm{mL}$ (rendah); saturasi transferin 5\%, hs-CRP 0,2 $\mathrm{mg} / \mathrm{L}$ (tidak meningkat). 


\section{Masalah klinis}

Kasus di atas menimbulkan pertanyaan klinis sebagai berikut: pada anak sehat usia sekolah apakah pemeriksaan RET-He dapat digunakan untuk mendeteksi adanya DB dibandingkan dengan pemeriksaan biomarker penanda status besi lain (feritin, saturasi transferin, kadar besi dalam serum dan TIBC)?

\section{Metode}

Pertanyaan klinis (PICO)

Patient $(\mathrm{P}) \quad$ : anak

Intervention (I) : pemeriksaan reticulocyte hemoglobin content (RET-He)

Comparison (C) : biomarker penanda status besi lain (feritin, saturasi transferin, kadar besi dalam serum dan TIBC)

Outcome $(\mathrm{O}) \quad$ : defisiensi besi

\section{Strategi pencarian}

Prosedur pencarian literatur untuk menjawab masalah di atas adalah dengan menelusuri pustaka secara online dengan menggunakan instrumen pencari Pubmed, Cochrane, ProQuest dan Google scholar.

\section{Kriteria seleksi}

Kata kunci yang digunakan adalah "iron deficiency", "reticulocyte haemoglobin content", dan "children" dengan menggunakan batasan: bahasa pengantar adalah bahasa Inggris, publikasi dalam rentang waktu 10 tahun terakhir pada anak sehat. Berdasarkan metode penelusuran dengan kriteria di atas, didapatkan 331 artikel, setelah ditelaah lebih lanjut terdapat 4 artikel yang dianggap relevan dengan masalah.

Keempat artikel yang sudah dipilih menjalani seleksi dengan alur sebagai berikut,

Tabel 1. Strategi penelusuran literatur (dilakukan pada tanggal 20 Juni 2018)

\begin{tabular}{llcc}
\hline Database & Strategi pencarian & Temuan & Digunakan \\
\hline Pubmed & $\begin{array}{l}\text { (iron deficiency[Titlel Abstract]) AND reticulocyte hemoglobin content[Titlel } \\
\text { Abstract]) AND children[TitlelAbstract] }\end{array}$ & 17 & 2 \\
Cochrane & iron deficiency AND reticulocyte hemoglobin content AND children & 0 & 0 \\
Google & iron deficiency AND reticulocyte hemoglobin content AND children & 307 & 4 \\
Scholar & {$[$ children "CHr"-adult] } & & \\
ProQuest & iron deficiency AND reticulocyte hemoglobin content AND children & 7 & 0 \\
\hline
\end{tabular}

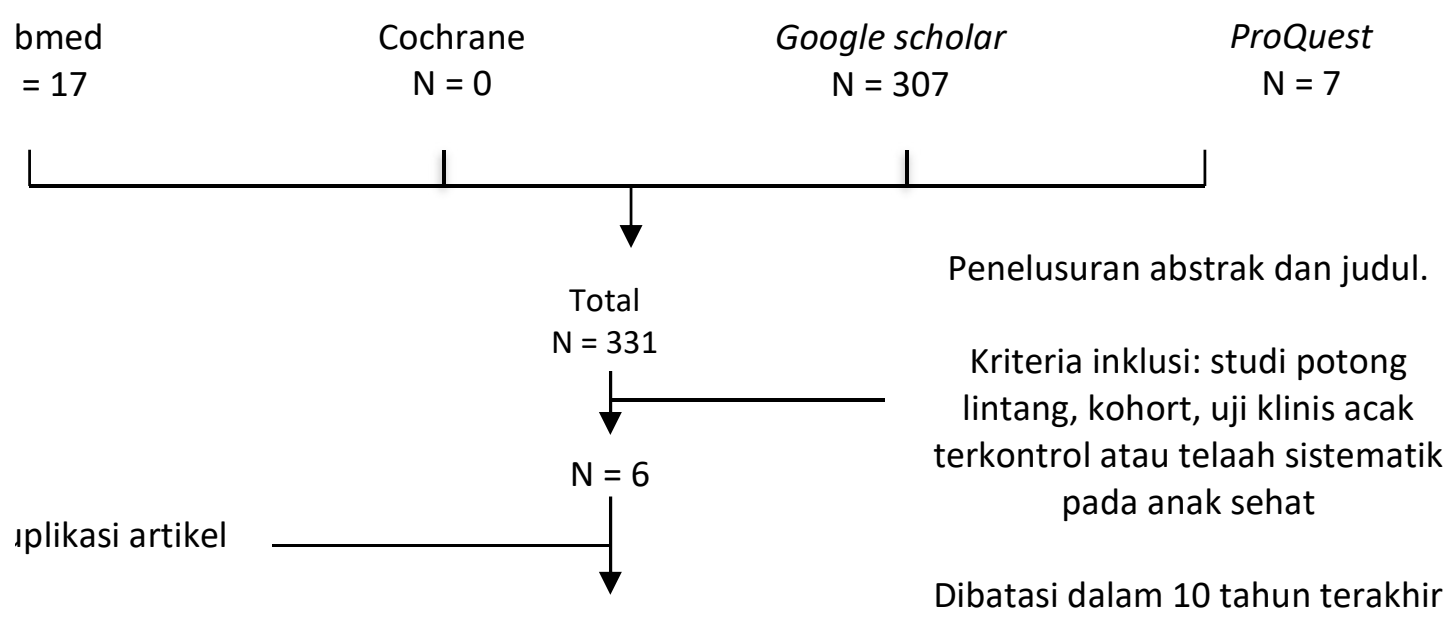

Gambar 1. Alur pemilihan literatur 


\section{Telaah kritis}

Empat artikel yang sesuai kemudian dilakukan telaah kritis berdasarkan kriteria dari Oxford Centre for Evidence-based Medicine ${ }^{14}$ untuk studi diagnostik. Hasil dari telaah kritis dapat dilihat pada Tabel 2 dan 3 . NDP-nilai duga positif; NDN-nilai duga negatif; AUC-area under curve; CI-confidence interval

\section{Hasil}

Sebuah studi potong lintang yang dilakukan oleh Mateos dkk, kepada 263 subyek yang berusia 6 bulan sampai 17 tahun dengan status ekonomi menengahkebawah yang berkunjung ke pusat kesehatan primer Spanish National Health Service di Madrid. Anak dengan riwayat penyakit kronis, kelainan darah, transfusi darah dalam 6 bulan terakhir, demam dalam waktu 1 bulan terakhir dan mendapat suplementasi zat besi dieksklusi dari penelitian ini. Subyek penelitian kemudian diperiksa kadar $\mathrm{Hb}, \mathrm{Ht}, \mathrm{MCV}, \mathrm{MCH}$, $\mathrm{MCHC}$, eritrosit, RET-He, leukosit dan hitung jenis, trombosit, feritin serum, saturasi transferin, transferin, kadar besi dalam serum dan TIBC. Prevalens DB sebesar 15,19\% dan untuk ADB sebesar 5,06\%. Prevalens DB pada anak usia kurang dari 24 bulan lebih tinggi, sebesar 38,23\% dari subyek kelompok usia tersebut. Dari studi tersebut dengan nilai batas RET$\mathrm{He} \leq 25$ pg didapatkan sensitivitas $94 \%$, spesifisitas 80\%, PPV 54\%, dan NPV 97\%. Likelihood ratio positif $(\mathrm{LR}+)$ studi ini sebesar 4,78 dan Likelihood ratio negatif (LR-) $0,08 . .^{15}$

Lorenz dkk, melakukan studi potong lintang restrospektif kepada 210 bayi dengan usia gestasi 23 minggu hingga 36 minggu. Seluruh pasien telah dilakukan pemeriksaan kadar $\mathrm{Hb}, \mathrm{Ht}, \mathrm{MCV}, \mathrm{MCH}$, feritin serum dan saturasi transferin. Dari studi tersebut dengan nilai batas RET-He $\leq 29$ pg, didapatkan sensitivitas 85\%, spesifisitas 73\%, PPV 33\%, dan NPV $97 \%$. Likelihood ratio positif studi ini sebesar 3,14 dan LR- $0,2 .^{5}$

Studi potong lintang juga dilakukan Pramantik dkk, tahun 2015 di Yogyakarta, terhadap 104 subyek anak sehat usia 6 bulan hingga 5 tahun pada yang menjalani pemeriksaan di Posyandu Kota Yogyakarta. Seluruh subyek dilakukan pemeriksaan $\mathrm{Hb}$, red blood cell (RBC), MCV, MCH, MCHC, red cell distribution width (RDW), RET-He dan feritin. Nilai batas RET-
He yang digunakan adalah $\leq 27,65 \mathrm{pg}$, didapatkan sensitivitas $91,7 \%$, spesifisitas 78,3\%, PPV 35,4\% dan NPV 98,63\%. Likelihood ratio positif studi ini sebesar 4,2 dan LR- 0,1. ${ }^{13}$

Kiudelienè dkk, juga melakukan uji potong lintang terhadap 180 subyek yang berusia 6 hingga 24 bulan yang dikonsultasikan ke unit rawat jalan Universitas Kaunas karena dicurigai DB. Kriteria inklusi dalam penelitian ini adalah subyek lahir cukup bulan dan berat lahir normal, tidak mengalami infeksi dalam 2 minggu sebelum sampel darah diambil (CRP $<5$ $\mathrm{mg} / \mathrm{L}$ ), tidak mendapat suplementasi besi dalam 1 bulan sebelum studi dilakukan. Seluruh subyek dilakukan pemeriksaan $\mathrm{Hb}, \mathrm{MCV}, \mathrm{MCH}, \mathrm{RDW}$, feritin serum dan transferin, saturasi transferin, RET-He, soluble transferrin receptors (TfR). Dari hasil pemeriksaan, subyek dibagi menjadi 2 kelompok, 116 subyek mengalami DB dan 64 subyek normal. Nilai batas RET-He adalah $\leq 28,55 \mathrm{pg}$, didapatkan sensitivitas 76,6\%, spesifisitas 78,4\%, PPV 86\% dan NPV 64\%. Likelihood ratio positif studi ini sebesar 3,4 dan LR- $0,2 .{ }^{16}$

\section{Pembahasan}

Idealnya suatu alat diagnostik harus memiliki sensitivitas yang tinggi untuk mengeksklusi penyakit dan spesifisitas yang tinggi menginklusi penyakit. Dari tabel 2, dapat dilihat bahwa studi Mateos $\mathrm{dkk}^{15}$ dan Pramantik $\mathrm{dkk}^{13}$ memiliki nilai sensitivitas dan spesifisitas yang hampir sama meskipun nilai batas RET-He yang berbeda yaitu $\leq 25$ pg dan $\leq 27,65$ pg. Sedangkan studi Lorenz $\mathrm{dkk}^{5}$ dan Kiudelienė $\mathrm{dkk}^{16}$ juga memiliki nilai sensitivitas dan spesifisitas yang hampir sama meskipun usia subyek dalam studi ini sangat bebeda, akan tetapi nilai batas RET-He yang digunakan hampir serupa yaitu $\leq 29 \mathrm{pg}$ dan $\leq 28,55 \mathrm{pg}$.

Perbedaan nilai batas RET-He pada setiap studi menurut penulis menjadi penyebab adanya perbedaan sensitivitas dan spesifisitas dalam beberapa studi diatas. Perbedaan nilai batas ini disebabkan karena belum ada referensi baku nilai batas yang pasti pada setiap kelompok usia yang berbeda dan ditentukan dari ratarata serta nilai batas yang paling optimal untuk mancari sensitivitas dan spesifisitas yang paling tinggi pada setiap studi. ${ }^{6}$ Selain perbedaan nilai batas RET-He, perbedaan kelompok usia pada setiap penelitian juga menjadi penyebab berbedanya nilai sensitivitas dan 
Tabel 2. Rangkuman telaah kritis

\begin{tabular}{|c|c|c|}
\hline $\begin{array}{l}\text { Artikel } \\
\text { Desain penelitian } \\
\text { Level of evidence }\end{array}$ & $\begin{array}{l}\text { Mateos dkk }{ }^{15}(2008) \\
\text { Studi potong lintang } \\
\text { 1c }\end{array}$ & $\begin{array}{l}\text { Lorenz } \mathrm{dkk}^{5}(2015) \\
\text { Uji retrospektif } \\
\text { 1c }\end{array}$ \\
\hline \multicolumn{3}{|c|}{$\begin{array}{l}\text { PICO } \\
\text { - P : anak } \\
\text { - I : pemeriksaan retic } \\
\text { - C : biomarker penan } \\
\text { - O : defisiensi besi }\end{array}$} \\
\hline Validitas & $\begin{array}{l}\text { Representative spectrum of patients: } \\
263 \text { subyek berusia } 6 \text { bulan - } 14 \text { tahun, dengan } \\
\text { sosial ekonomi menengah bawah } \\
\text { Kriteria eksklusi : riwayat penyakit kronik, } \\
\text { kelainan darah, transfusi darah dalam } 6 \text { bulan } \\
\text { terakhir, demam } 1 \text { bulan terakhir, pemberian } \\
\text { suplementasi besi. } \\
\text { Reference standard: } \\
\text { Diagnosis DB dan ADB ditegakkan dengan } \\
\text { pemeriksaan darah (setelah puasa): Hb, Hct, } \\
\text { MCV, MCHC, RDW, CHr, leukosit, differential } \\
\text { count, platelet, ferritin, saturasi transferin, } \\
\text { transferin, serum iron dan TIBC. } \\
\text { Blind comparison to gold standard: Pemeriksaan } \\
\text { menghasilkan nilai CHr (rerata kadar } \\
\text { hemoglobin seluler retikulosit). Parameter } \\
\text { tersebut dihasilkan oleh Technicon H*3 (Bayer } \\
\text { Diagnostics, Tarrytown, NY, USA), tidak } \\
\text { dilakukan blinding. } \\
\text { Kesimpulan: sahih (valid) }\end{array}$ & $\begin{array}{l}\text { Representative spectrum of patients: } \\
210 \text { bayi dengan usia gestasi } 23 \text { minggu hingga } 36 \\
\text { minggu atau berat badan lahir }<1500 \mathrm{~g} \text { pada saat } \\
\text { usia 3-4 bulan usia koreksi. } \\
\text { Dilakukan delayed cord clamping pada semua } \\
\text { partisipan ( } 45 \text { detik). Semua partisipan mendapat } \\
\text { suplementasi besi sesuai usia dan mendapat susu } \\
\text { formula BBLR atau ASI dengan fortifikasi } \\
\text { Kriteria eksklusi : kelaianan hematologi } \\
\text { Reference standard: } \\
\text { Pemeriksaan CHr saat usia 3-4 bulan, MCV, TS, } \\
\text { ferritin, Hb. } \\
\text { Defisisensi besi bila memenuhi } 2 \text { dari } 3 \text { kriteria } \\
\text { berikut: } \\
\text { 1. MCV< } 75 \mathrm{fL} \\
\text { 2. TS }<10 \% \\
\text { 3. Ferritin }<30 \text { ug/L } \\
\text { Blind comparison to gold standard: } \\
\text { Pemeriksaan menghasilkan nilai CHr dilakukan } \\
\text { secara otomatis dengan alat ADIVA } 120 \\
\text { (Siemens, Eschborn, Germany), tidak dilakukan } \\
\text { blinding. }\end{array}$ \\
\hline Importance & $\begin{array}{l}\text { Cut-off: } \leq 25 \mathrm{pg} \\
\text { Sensitivitas : } 94 \% \\
\text { Spesifisitas : } 80 \% \\
\text { NDP } \quad: 54 \% \\
\text { NDN } \quad: 97 \% \\
\text { AUC } \quad: 0,9277\end{array}$ & $\begin{array}{l}\text { Cut-off: } \leq 29 \mathrm{pg} \\
\text { Sensitivitas : } 85 \% \\
\text { Spesifisitas : } 73 \% \\
\text { NDP } \quad: 33 \% \\
\text { NDN } \quad: 97 \% \\
\text { AUC } \quad: 0,86\end{array}$ \\
\hline Applicability & $\begin{array}{l}\text { Methods permit replication: } \\
\text { Metode penelitian menjelaskan secara detail uji } \\
\text { diagnostik untuk diaplikasi pada populasi. }\end{array}$ & $\begin{array}{l}\text { Methods permit replication: } \\
\text { Metode penelitian menjelaskan secara detail uji } \\
\text { diagnostik untuk diaplikasi pada populasi. }\end{array}$ \\
\hline
\end{tabular}


Tabel 3. Rangkuman telaah kritis

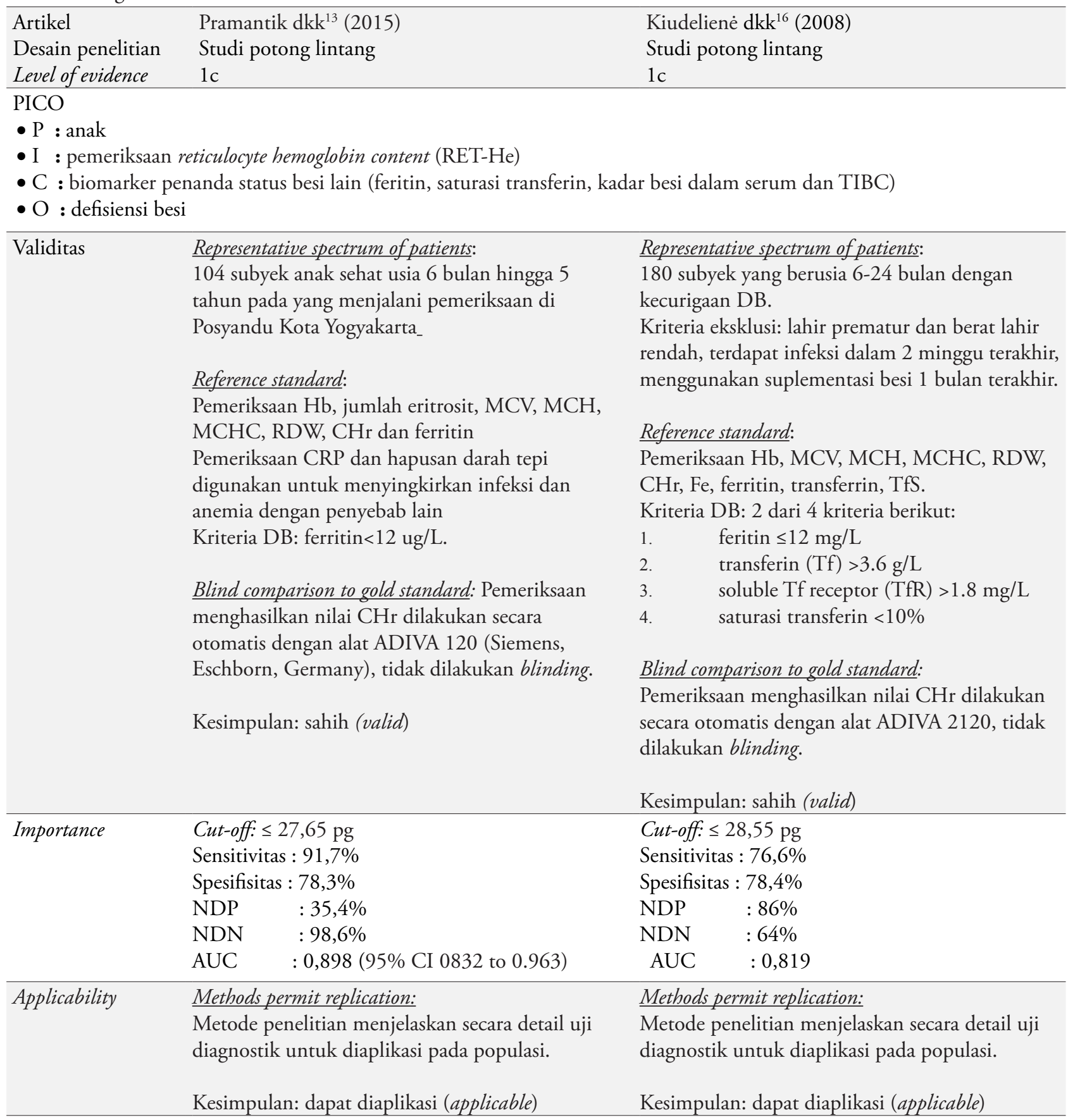

spesifisitas, khususnya pada studi Lorenz $\mathrm{dkk}^{5}$, subyek penelitian merupakan bayi prematur (usia gestasi $<32$ minggu) atau berat badan lahir $<1500 \mathrm{~g}$ pada saat usia 3-4 bulan usia koreksi.

Sebuah studi lain pada tahun 2016 dilakukan untuk mengatahui nilai batas RET-He pada anak sehat berdasarkan kelompok usia, jenis kelamin dan status gizi overweight atau tidak. Berdasarkan kelompok usia, nilai batas yang digunakan adalah dibawah persentil 2,5 menunjukkan nilai RET-He yang rendah, yaitu usia $1-2$ tahun $\leq 25,5$ pg, usia $2-5$ tahun $\leq 27,3$ pg, usia 6-8 tahun $\leq 27,6$ pg dan usia 9-11 tahun $\leq 28,1$ pg. ${ }^{6} \mathrm{Hal}$ 
inilah yang menurut penulis menjadi dasar perbedaan nilai sensitivitas dan spesifisitas pada setiap studi.

Studi yang dilakukan di Jakarta, tahun 2016 pada anak usia sekolah dengan rerata usia subyek 11,6 tahun menunjukkan nilai batasan RET-He untuk skrining DB adalah 27,55 pg dengan sensitivitas 87,5\%, spesifisitas 75\%, PPV 24\%, NPV 98,5\%, LR+ 3,5, LR- 0,16, akurasi 0,77. Sedangkan nilai batasan RET-He untuk skrining ADB adalah $26,85 \mathrm{pg}$ dengan sensitivitas $100 \%$, spesifisitas $83 \%$, PPV 17\%, NPV 100\%, LR+ 0,58, LR- 0, akurasi 0,84. Dalam studi ini juga dilakukan penilaian untuk mendeteksi adanya deplesi besi pada anak dengan nilai batas RET-He $\leq 29,65$ pg, akan tetapi nilai sensitivitas dan spesifisitas rendah, yaitu sebesar $44 \%$ dan $40 \%$. Hal ini disebabkan karena jumlah subyek yang diikutsertakan dalam penelitian terlalu sedikit dengan prevalens sebesar 2,8\%. Studi ini bisa diterapkan pada kasus dengan karakteristik populasi rentang usia sekolah, akan tetapi penelitian ini tidak dimasukkan dalam telaah kritis karena belum dipublikasi. ${ }^{8}$

Parameter pembanding nilai RET-He yang digunakan untuk menilai status besi pada beberapa studi diatas bebeda-beda, akan tetapi secara keseluruhan memiliki kesaamaan parameter pembanding menggunakan $\mathrm{Hb}, \mathrm{MCV}, \mathrm{MCH}$, feritin dan saturasi transferin kecuali pada studi yang dilakukan oleh Primantik $\mathrm{dkk}^{13}$ tidak dilakukan pemeriksaan saturasi transferin. Studi ini menggunakan feritin sebagai baku emas untuk skrining DB dengan nilai batas $\leq 12$ pg. ${ }^{13}$ Dalam sebuah referensi disebutkan bahwa pemeriksaan baku emas yang digunakan untuk menilai adanya DB adalah saturasi transferin $<10 \%$ pada usia berapapun memiliki sensitivitas dan spesifisitas $100 \%$. Sedangkan pemeriksaan lain yang dapat dijadikan parameter skrining DB adalah kadar RET-He, feritin dan MCV. Sensitivitas dan spesifisitas RET-He dengan nilai batas $\leq 27,5$ pg pada usia $9-12$ bulan sebesar $83 \%$ dan $72 \% .^{10}$ Nilai ini hampir serupa dengan nilai sensitivitas dan spesifisitas dalam 3 studi yang ditelaah diatas, kecuali studi Kiudelienè dkk, ${ }^{16}$ memiliki sensitivitas dan spesifisitas lebih rendah karena menggunakan nilai batas RET-He yang lebih tinggi yaitu $\leq 28,55 \mathrm{pg}$.

Kasus ini menunjukkan nilai RET-He yang rendah yaitu 25,7 pg, sesuai dengan batasan yang digunakan oleh Pramantik dkk, ${ }^{13}$ menggunakan nilai batas RET$\mathrm{He} \leq 27,65$ pg dengan nilai sensitivitas dan spesifisitas sebesar $91,7 \%$ dan $78,3 \%$. Nilai batas yang digunakan pada studi tersebut sesuai dengan hasil studi yang menilai batas RET-He berdasarkan kelompok usia, yaitu rentang usia 6-8 tahun $\leq 27,6$ pg. ${ }^{6}$ Parameter pendukung lain berupa kadar $\mathrm{Hb}$ normal, yaitu 12,6 $\mathrm{g} / \mathrm{dL}$ serta kadar feritin dan nilai saturasi transferin yang rendah pada pasien sebesar 9,49 $\mathrm{ng} / \mathrm{mL}$ dan $5 \%$ sehingga mengkonfirmasi diagnosis DB pada kasus ini.

Kriteria diagnosis DB yang dikutip dari kriteria NHANES III (National Health and Nutrition Examination Survey) bila terdapat 2 atau lebih tanda berupa nilai saturasi transferin $<10 \%$ (usia 1-2 tahun), $<12 \%$ (usia 3-5 tahun), < 14\% (usia 4-11 tahun), kadar feritin $<10 \mathrm{ng} / \mathrm{mL}$ (usia $1-5$ tahun), $<12 \mathrm{ng} / \mathrm{mL}$ (usia 6-11 tahun), eritrosit porfirin (EP) $>80 \mu \mathrm{g} / \mathrm{dL}$ (usia 1-2 tahun) dan $>70 \mu \mathrm{g} / \mathrm{dL}$ (usia 2-11 tahun). Kondisi infeksi juga telah disingkirkan pada kasus ini dengan nilai CRP $0,2 \mathrm{mg} / \mathrm{L}^{6,17}$

Apabila melihat rentang usia pada kasus, studi yang bisa diterapkan untuk kasus ini adalah studi Mateos $\mathrm{dkk}^{15}$ dan Primantik dkk, ${ }^{13}$ sedangkan studi Lorenz $\mathrm{dkk}^{5}$ tidak bisa diterapkan karena subyek penelitiannya merupakan bayi prematur (usia gestasi < 32 minggu) atau berat badan lahir $<1500$ g pada saat usia 3-4 bulan usia koreksi. Studi Primantik dkk, ${ }^{13}$ validitasnya dinilai kurang karena tidak dilakukan pemeriksaan pembanding dengan baku emas yang memiliki sensitivitas dan spesifisitas $100 \%$ yaitu nilai saturasi transferin. ${ }^{12}$

Pemeriksaan RET-He cenderung lebih murah dan lebih praktis apabila dibandingkan paramater laboratorium lainnya untuk mendeteksi DB. Nilai RET-He didapatkan secara otomatis saat melakukan pemeriksaan darah lengkap. Biaya yang diperlukan untuk melakukan hitung darah lengkap dan RETHe lebih murah 5 kali lipat dibandingkan dengan pemeriksaan biomarker besi lain. ${ }^{5}$ Selain itu dari segi pengambilan darah juga lebih sedikit sehingga dapat digunakan untuk mengganti paramater lainnya. RETHe dapat mendeteksi lebih cepat adanya DB dan mempercepat tatalaksana besi pada pasien.

Ikatan Dokter Anak Indonesia merekomendasikan skrining DB dilakukan pada populasi dengan risiko tinggi seperti bayi dengan kondisi prematur, berat lahir rendah, riwayat mendapat perawatan lama di unit Neonatologi, dan anak dengan riwayat perdarahan, infeksi kronis, etnik tertentu dengan prevalens anemia yang tinggi, mendapat ASI ekslusif tanpa suplementasi, mendapat susu sapi segar pada usia dini, dan faktor risiko sosial lain. ${ }^{3}$ Pada anak usia sekolah (5-12 tahun) dan remaja lelaki, CDC hanya merekomendasikan pemeriksaan $\mathrm{Hb}$ dan $\mathrm{Ht}$ pada individu dengan riwayat $\mathrm{ADB},{ }^{3,18}$ 


\section{Kesimpulan}

Berdasarkan penelitian ilmiah yang telah dipaparkan sebelumnya dapat disimpulkan bahwa pemeriksaan dengan menggunakan RET-He dapat digunakan sebagai parameter untuk mendeteksi DB pada anak.

\section{Saran}

Laboratorium di Rumah Sakit di Indonesia menyediakan alat pemeriksaan yang bisa digunakan untuk analisis RET-He secara langsung dari sampel pemeriksaan darah lengkap.

\section{Daftar pustaka}

1. Bakr AF, Sarette G. Measurement of reticulocyte hemoglobin content to diagnose iron deficiency in Saudi children. Eur J Pediatr. 2006;165:442-5.

2. World Health Organization. Iron deficiency anaemia: assessment, prevention and control. Geneva: World Health Organization; 2001. h:3-5.

3. Gatot D, Idjradinata P, Abdulsalam M, Lubis B, Sujatmiko, Hendrato A, dkk. Rekomendasi Ikatan Dokter Anak Indonesia, suplementasi besi untuk anak. Edisi ke-1. Jakarta: Badan Penerbit IDAI; 2011. h:1-5.

4. Rungngu SLP, Wahani A, Mantik MFJ. Reticulocyte hemoglobin equivalent for diagnosing iron deficiency anemia in children. Paediatr Indones. 2016;56:90-4.

5. Lorenz L, Arand J, Büchner K, Wacker-Gussmann A, Peter A, Potes CF, dkk. Reticulocyte haemoglobin content as a marker of iron deficiency. Arch Dis Child Fetal Neonatal Ed. 2015;100:198-202.

6. Lopez-Ruzafa E, Vazquez-Lopez MA, Lendinez-Molinos F, Poveda-Gonzales J, Galera-Martinez R, Bonillo-Paralez A, $\mathrm{dkk}$. Reference values of reticulocyte hemoglobin content and their relation with other indicators of iron status in healthy children. J Pediatr Hematol Oncol. 2016;38:207-12.

7. Nawangwulan SA, Andriastuti M, Devaera Y, Dewi R.
Status besi siswa sekolah dasar negeri di Jakarta : hubungan dengan status gizi dan asupan diet, studi kasus di SD Negeri Pegangsaan 01 Jakarta Pusat [tesis]. Jakarta: Universitas Indonesia; 2016.

8. Adiwijaja M, Andriastuti M, Satari HI. Reticulocyte hemoglobin content sebagai parameter skrining status besi pada anak [tesis]. Jakarta: Universitas Indonesia; 2018.

9. Andriastuti M, Palupi SR, Medyatama MF. Iron status of adolescent and young adults at slum area in Bekasi, West Java. unpublished

10. Flemming MD. Disorders of iron and cooper metabolism, the sideroblastic anemias, and lead toxicity. Dalam: Orkin $\mathrm{SH}$, Fisher DE, Ginsburg D, Look AT, Lux SE. Nathan and Oski’s hematology of infancy and childhood. Edisi ke-8. Philadelphia: Elsevier; 2015. h. 344-64.

11. Uijterschout, Domellöf M, Vloemans J, Vos R, Hudig C, Bubbers S, dkk. Maternal and pediatric nutrition highlights original article. The value of Ret-Hb and sTfR in the diagnosis of iron depletion in healthy, young children. Eur J Clin Nutr. 2014;68:882-6.

12. Kuehn D, Roberts SR, Olsen CH, Harvey DN, Charnock CKM, Brewer BD, dkk. Reticulocyte hemoglobin content testing for iron deficiency in healthy toddlers. Military Medicine. 2012;177:91-5.

13. Pramantik DN, Ratnaningsih T, Mulyono B. Iron deficiency screening with content hemoglobin reticulocyte (chr) in children aged 6 months to 5 years. J Med Sci. 2015;47:115-21.

14. Oxford Centre of Evidence-Based Medicine 2011 Levels of Evidence. 2011 [disitasi pada tanggal 20 Juni 2018]. Tersedia di: http://www.cebm.net/ocebm-levels-of-evidencel

15. Mateos ME, De-La-Cruz J, Lopez-Laso E, Valdes M, Nogales A. Reticulocyte hemoglobin content for the diagnosis of iron deficiency. J Pediatr Hemotol Oncol. 2008;30:7.

16. Kiudelienè R, Griniūtė R, Labanauskas L. Prognostic value of reticulocyte hemoglobin content to diagnose iron deficiency in 6-24-month-old children. Medicina. 2008;44:9.

17. Looker AC, Dallman PR, Carrol MD, Gunter EW, Johnson CL. Prevalence of iron deficiency in the United States. JAMA. 1997;277:12.

18. Centers for Disease Control and Prevention. Recommendation to prevent and control iron deficiency in United States. 1998. 